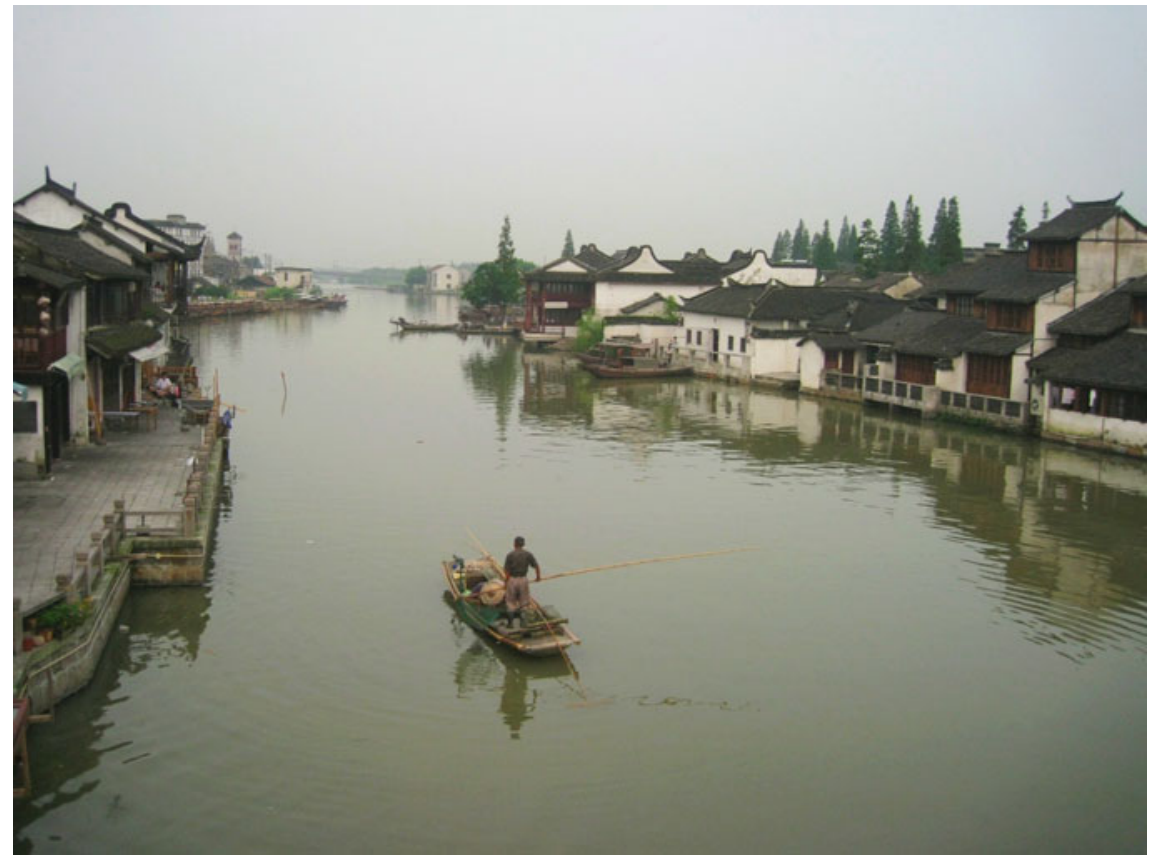

The Zhujiajiao water town, China, 2009, Wikimedia, Anna Frodesiak, Public Domain 


\title{
Chapter 15 \\ Neglected and Undervalued Cultural \\ Heritage: Waterfronts and Riverbanks of Alblasserwaard, The Netherlands
}

\author{
Arie den Boer
}

One of the best things about water is the look and feel of it.... It's not right to put water before people and then keep them away from it.

—William H. Whyte (1975).

\begin{abstract}
Alblasserdam is a Dutch dyke village dating to the thirteenth century, with its earliest houses built along the embankment of a major dyke. Most of its history is closely related to shipping and shipbuilding. The village center had a harbor for inland ships and a navigation lock; in the hinterland, industrialization created several yards where workers built many types of vessels: simple wooden rowing boats, wooden ships, and steel ships. Other yards related to shipbuilding - a steel mill, a construction yard for railway infrastructure - rose there too. The material used in these yards came in by ship and ferry. Today, the local ferry has been replaced by bridges and a tunnel. Sites once hosting major shipyard now hold housing. Halls that were used to build minesweepers for the Dutch Navy are now used for building beautiful yachts. Cranes and old buildings alike have disappeared, and new areas have become available for redevelopment. Five objects on the waterfront of the Noord exemplify the connections of history to possible transformations in the future, and the question of safeguarding the area's history as cultural heritage: the site of the Nedstal steel factor, the historic bridge (and an art installation proposed for it), the shipyard of van de Giessen de Noord, the Oude Werf yard, and the Mercon Kloos site. Two citizen initiatives seek to restore and manage cultural heritage in the Alblasserwaard and the river Noord. The analysis shows that cultural heritage has gotten more attention from public and private stakeholders and civil society over time.
\end{abstract}

Keywords Citizen participation $\cdot$ Water heritage $\cdot$ Public space $\cdot$ Riverfront $\cdot$ River art $\cdot$ Alblasserwaard

\footnotetext{
A. den Boer $(\varangle)$

Erasmus University Rotterdam, Rotterdam, The Netherlands

e-mail: arie.den.boer@planet.nl 


\section{Introduction}

Until 1977, urban riverfront areas around the world hosted factories, industrial plants, warehouses, harbor facilities, and railways. Typically, they were significantly separated from the surrounding urban fabric (Estevens 2005). But with the evolution of maritime technology and of post-industrial cities, port cities gradually lessened their dependence on port activities. Modern shipping required more space, deeper water, and more extensive port facilities. Riverfronts lost their port functions. Today, seafronts, riverfronts, and lakefronts that were once the industrial birthplace of many cities have become prime locations for new development. Many reimagine a working waterfront as a multi-use public gathering place, and a golden opportunity for a city to redefine itself (Whyte 1975). During recent decades, port cities have restructured themselves and their waterfronts, and many scholars and practitioners have written about riverfront improvement, regeneration, and redevelopment in many cities (Harms 2008). The HafenCity project in Hamburg is an interesting example of possibilities for waterfront development (HafenCity Hamburg 2017).

Along with the city's Kontorhausviertel (or "Trading House District") and Chilehaus ("House of Chile"), the Speicherstadt, a historic warehouse district, has been included on the list of UNESCO World Heritage Sites and is a must-see on every journey to Hamburg (HafenCity Hamburg 2000). The planning for HafenCity was guided by several goals: to reunite the city with the waterfront; to revitalize the waterfront to create jobs and revenue; to benefit port, city, and state; to provide parks, plazas, walkways, and public open space at the water's edge; and to respect the historic character of the waterfront (Harms 2007).

In contrast, Alblasserdam is a neglected and underdevalued site of cultural heritage. It is one of the landscapes surrounded by water in the Rhine-Meuse-Scheldt delta, the Alblasserwaard, and it lies along the tidal river Noord on the west side of the water between Lek and Beneden-Merwede from Rotterdam to Dordrecht. This paper presents an overview of historical and heritage-related narratives of its waterfront, of current debates over its fate, and some future options. It aims to show the complexity of heritage, with its mixture of historical values, economic considerations, safety issues, river art development, and much more. As such, this paper does not claim to offer a clear example of how to do things in heritage policy, nor an analysis deeply anchored in theories of heritage and change. It is a simple but important message is that heritage policies and debates are inherently messy; many agents with many claims and interests discuss what they consider to be valid steps to take when developing an area. This article also shows the complexity of the decision-making process and concludes by considering how various models of negotiation might take the analysis further. 


\section{The Alblasserwaard as Focus of Waterfront Heritage}

Most tourists to the Netherlands have heard of the canals in Amsterdam, the capital of the Netherlands, or the riverbanks of Rotterdam, one of the largest harbors in the world. Not so many, however, have heard about the Alblasserwaard and its dyke ring, which nature, water management, building, and industrialization have shaped since 1277. Its embankments protect the Alblasserwaard from inundation both from water from the sea at high tides and the flooding of the rivers Rhine and Meuse from Switzerland, Germany, and France; the local saying is that the "water-wolf could strike from two directions (Louwe Kooijmans 1974). Complaints about the Alblasserwaard and Alblasserdam being neglected go a long way back; Boersma said that no writing had left the printing press that described in detail the history of the dyke city that stretched along the Noord (Boersma 1939). But today, a company called DEAL! Drecht Cities, the central marketing and promotion agency of the six Drecht Cities, is finally promoting Alblasserdam (Deal Drecht Cities 2018).

Alblasserdam is the main village on the west side of the river Noord, and it celebrated its 700th anniversary in 1999. The publication “Alblasserdam 1299-1999," written under supervision of the municipality, says that 1299 may actually be a conservative estimate, as it is the date of a document that describes founding father Nicolaas van Souburgh as already in the region (De Reus 1998).

Alblasserdam is named after the peat river Alblas and the dam that was built where the Alblas connected to the Noord, a larger river (De Wit 2009). Originally, the dam had three culverts to control the water level in the lower-lying ward. At the end of sixteenth century, these culverts were converted to a navigation lock with wooden point doors. The city grew on the dyke and in the center of the dyke ring. On May 10, 1940, the center of Alblasserdam was bombed and destroyed; the townspeople rebuilt it in the Delft School style, a movement that promoted architectural traditionalism in between 1925 and 1955 .

Most of the city's history is closely related to shipping and shipbuilding. The village center had a harbor for inland ships and a navigation lock; in the hinterland, industrialization created several yards where workers built many types of vessels: simple wooden rowing boats, wooden ships, and steel ships. Other yards related to shipbuilding — a steel mill, a construction yard for railway infrastructure-rose there too. The material used in these yards came in by ship and ferry.

Recently, these yards have seen huge changes. The steel factory Nedstaal went bankrupt and the site of Mercon Kloos, a railway infrastructure company, has been acquired by a project developer, Whoonapart (Poldervaart 2017a, b). The van der Giessen de Noord shipyard is now a shipyard called oceAnco. The land of the Oude Werf yard has been used for houses and apartments. A location on the riverbank is marked for a jetty to be used by the waterbus, which connects Dordrecht with Rotterdam with Papendrecht, Hendrik-Ido-Amacht- Alblasserdam, Ridderkerk, and Krimpen aan de IJssel.

Alblasserwaard is radically changing, raising many questions about what to do with the areas that have changed, that will change, and that might well need to change. 
Five objects on the waterfront of the Noord exemplify the connections of history to possible transformations in the future, and the question of safeguarding the area's history as cultural heritage: the site of the Nedstaal steel factor, the historic bridge (and an art installation proposed for it), the shipyard of van de Giessen de Noord, the Oude Werf yard, and the Mercon Kloos site. Stakeholders are discussing-and thus shaping - the town's present and the future, with current views becoming history over time and cultural heritage standing as witness and proof of the past. In our participatory society, stakeholders use their citizenship networks to put up a vote, a voice, or an initiative to give direction to — or at least influence — the decision making process on the transformation of the urbanized riverbanks in the region.

\section{The River Noord and Alblasserdam}

In 1277, the dyke ring of the Alblasserwaard (Fig. 1) was fitted with locks at Kinderdijk/Elshout, and Alblasserdam to be able to control the water level in the Waard's polders: Polder Blokweer, Polder Het Nieuwland, Polder Kortland, Polder Souburg, and Vinkenpolder. Farming and fishing villages like Alblasserwaard rose around the locks, later adding shipbuilding and iron works. Transport overland was restricted to a small network of local tracks until the nineteenth century. Rivers had to be crossed with a ferry, as fixed crossings were not created until the twentieth century (Van Groningen 1992). The bridge over the river De Noord replaced the ferry between Alblasserdam and Oostendam in 1939, part of a 1927 national road plan (rijkswegenplan) (Autosnelwegen 2018). Originally, that bridge was part of highway A15, but with increased traffic pressure it became a bottleneck. A tunnel under the river at the same crossing was the solution, and in 1992, the Noordtunnel was inaugurated. The original bridge now carries local traffic and hazardous materials not allowed through the tunnel. It is still an icon of Alblasserdam and the river Noord and is clearly visible from land, water, and air.

Shipyards were built on both sides of the Alblasserdam harbor. Behind the earliest yard (De Oude Werf) and to the north of the village, a second yard (Mercon Kloos) for railway infrastructure material was built in 1843. In 1936, a steel mill (Nedstaal) was built on the existing yard of Van de Giessen de Noord on the south side. Every shipyard has its own history, written by amateur historians.

In 1950, the Oude Werf was sold to the shipbuilding magnate Cornelis Verolme. Pictures from that year show a shipyard that still has a saw mill. He continued the company, renaming it Verolme Shipyard Alblasserdam (V. S. A.) in 1957. Verolme's redevelopment approach was economically driven, without much attention to the past or heritage. Both intangible and tangible assets of the past disappeared during his tenure. For example, in March 1952, the log pond was filled to become a plot for redevelopment, and later that same year, the sawmill was removed for the same spatial development plan (Alblaserdam net 2018). De Hollandse Molen foundation had been afraid that the sawmill would fall victim to industrialization and luckily found a municipality that was interested in it; the dismantled sawmill, named "Ons 


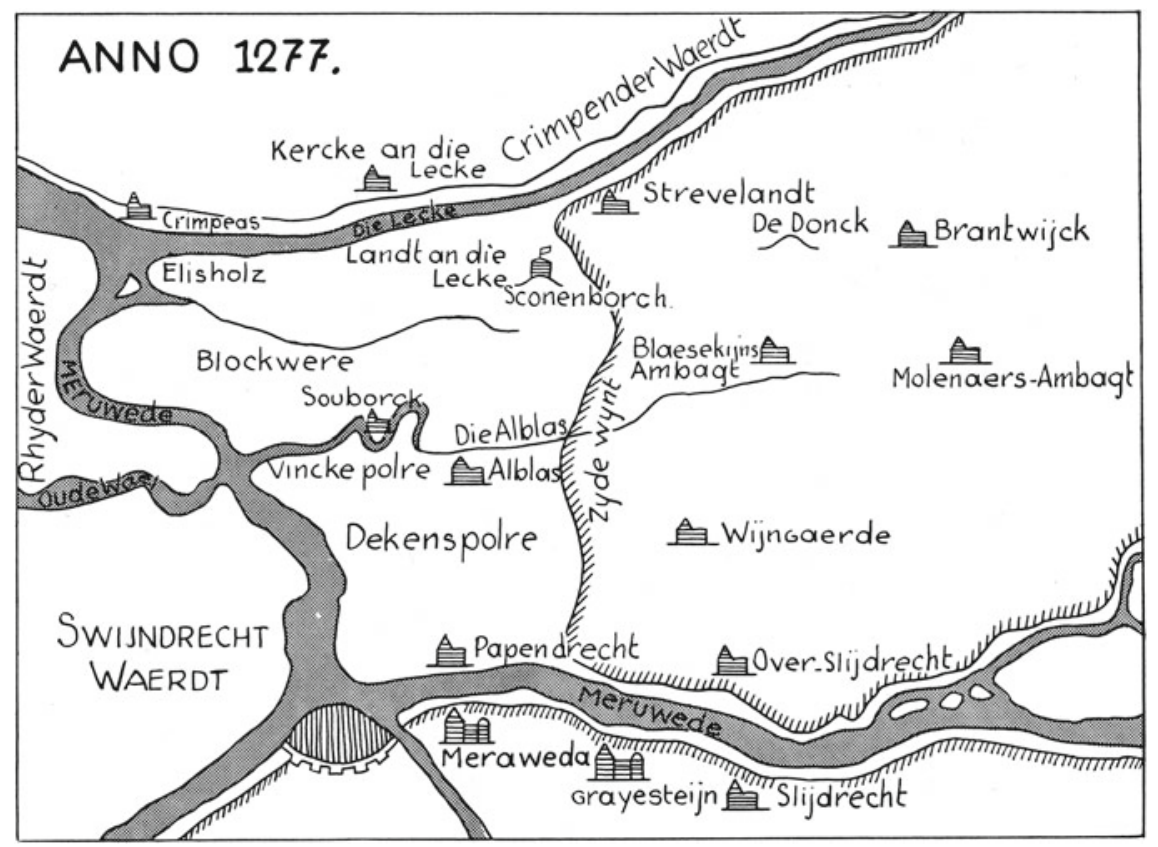

Fig. 1 Alblasserwaard in 1277, with the dyke ring at Zyde wynt (Zijdeweg) (Boersma 1939); released under a Creative Commons Attribution-NonCommercial-NoDerivatives 4.0 International License

Genoegen" (Molendatabase 2018) went to Haarlem. In 1973, parts of it were used to rebuild the "De Kat" mill in Uitgeest after it burned.

In 1977, the Verolme yard was connected with a bridge over the harbor to the Van de Giessen de Noord shipyard. That yard was now used to build subsections for the main yard. In turn, van de Giessen de Noord sold the Verolme yard in 2000 to a project developer and the municipality. The area was no longer needed for shipbuilding and was available for redevelopment. The former Verolme site was the first major building area to expand the built-up area of Alblasserdam.

The municipality collaborated with a project developer, Alblasserwerf CV (Bouwcombinatie Alblasserwerf 2004) and an architectural firm, HVE Architecten (HVE Architecten 2001) to plan 403 homes (60\% apartments and $40 \%$ houses) in a new residential area, Alblasserwerf, and to plan accompanying public space (Municipality Alblasserdam 2012). The redevelopment was hit by the financial crisis, which raised concerns about financial viability. It was adapted accordingly: in order to finance the project, more houses had to be built on the Verolme location. Some attention to heritage could be kept. A 2001 study recommended keeping part of the building slip foundation, with an area of plank bridges symbolizing the now-filled log pond. But when the private partner ran into problems and sold out, the municipality reconsidered the plans, guided by BBN advisors, a Dutch real estate and construc- 


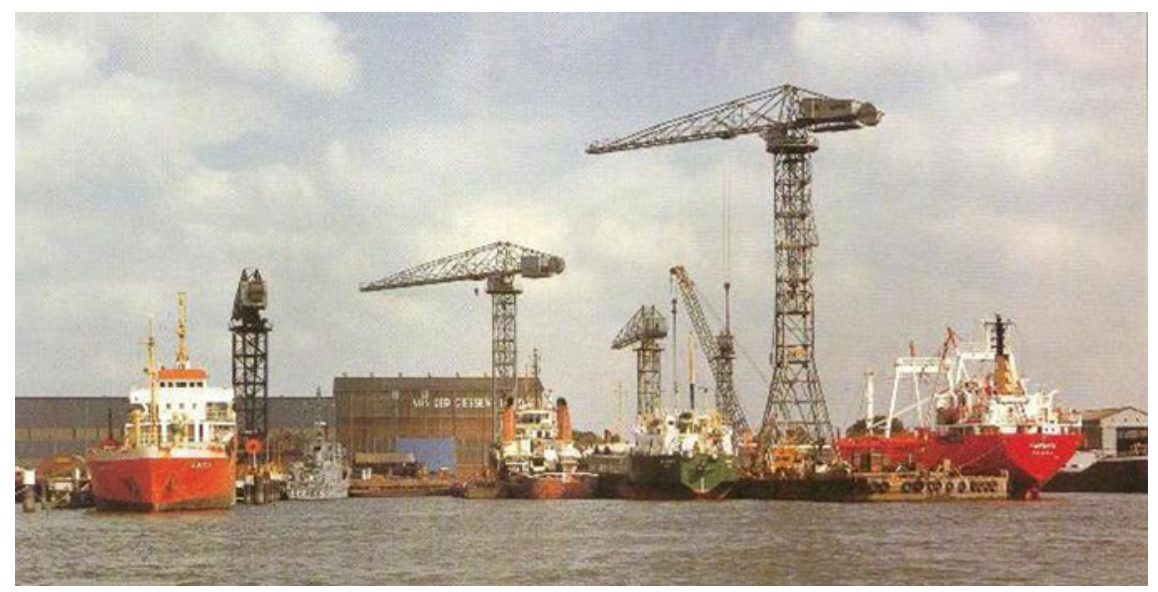

Fig. 2 Shipyard Van de Giessen de Noord at the end of the twentieth century. The last two tower cranes were demolished April 23, 2009. Source Homoet 2017; released under a Creative Commons Attribution-NonCommercial-NoDerivatives 4.0 International License

tion consultant. (BBN Adviseurs 2009). This was a second reconsideration of the plan, adding more space to make it economically and logistically feasible. Today, the redevelopment is in its final stage, with the new waterbus jetty located on the De Noord river, close to the former yard at the Jan Smit kade (quay), named after the founder of the shipyard (Homoet 2018a). In 2000, there were plans to expand the Van der Giessen de Noord shipyard, which built luxury ferries (Fig. 2). But after the attack on the World Trade Centre in New York on September 11, 2001, orders suddenly dropped. In September 2002, the company reorganized, shedding a third of its staff, but despite many good contacts with shipping companies, no orders came in. As a result, on August 25, 2003, the management of van der Giessen de Noord sadly announced that the company was closing its gates (Homoet 2018b).

In 1936, the Nederlandse Kabelfabriek (NKF) founded a steel factory, Nedstaal, in Alblasserdam; it also founded another similar steel company, Corus Ijmuiden (its current name). Nedstaal was important to the early development of the municipality of Alblasserdam, especially in terms of the employment it offered (Telegraaf 2014). But it had financial problems in the early twenty-first century and finally closed on January 31, 2017 (Rotterdam District Court 2014). The municipality board and council met confidentially with the Drechtsteden Regional Development Company (ROM-D) on March 13, 2018 to discuss the redevelopment of the site.

The Mercon Kloos shipyard was built in 1843 near Oost Kinderdijk. It has adapted to the economic development of the Netherlands and general market needs, building large items from ships to rail infrastructure material. In August 2004, it moved its activities to the former property of the shipyard Van de Giessen de Noord in Krimpen aan den IJssel. 
Thus, over time, more stakeholders were involved in the planning and redevelopment of historic sites, more attention was paid to sites' surroundings, and planners took more criteria like heritage into account.

\section{Cultural Heritage on the Riverbanks}

The forelands of the river Noord were developed for industrial activity, especially shipbuilding and steelmaking. Companies chose this location for economic and logistical reasons, including the price of land, access to the river, and the availability of cooling water. The shipbuilding industry, like other industries, continuously modernized production procedures and products to meet global competition. Facilities had to change or become obsolete. Whether they become an active part of the area's history in the shape of industrial, cultural, or other heritage depends on all kinds of discussions, actions, and interests. Five objects on the waterfront of the Noord (Fig. 3) exemplify the connections of history to possible transformations in the future, and the question of safeguarding the area's history as cultural heritage: the Nedstaal site, a proposed art installation on the bridge, the shipyard of van de Giessen de Noord, the Oude Werf yard, and the Mercon Kloos site.

Nedstaal went bankrupt on January 31, 2017 (Fig. 4). The company owned the site with FN Steel; now, the 36 hectare area and its buildings are owned by Ruigenhil Vastgoed B. V. Nedstaal's assets were removed in April, including the river crane,

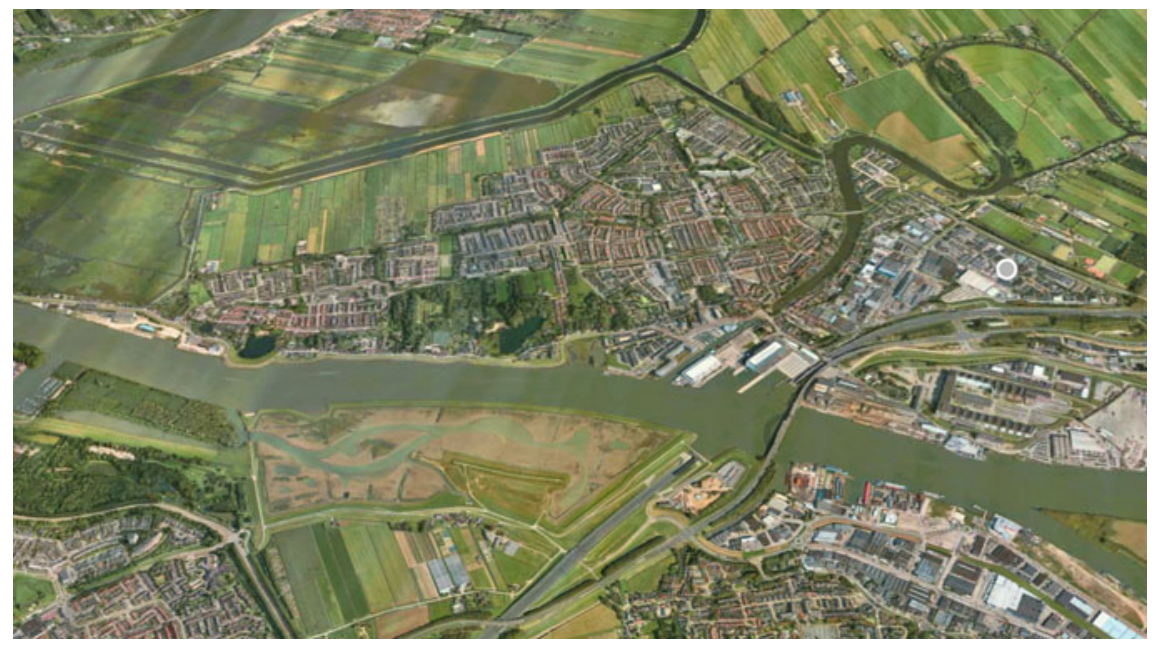

Fig. 3 Alblasserdam riverbanks: 1. Mercon Kloos; 2. Alblasserwerf (former 'De Oude Werf transformed to housing); 3. OceAnco (former 'van de Giessen de Noord'; 4. Bridge over river Noord; 5. Nedstaal. Photograph Cees van de Wal Fotografie and Film; released under a Creative Commons Attribution-NonCommercial-NoDerivatives 4.0 International License 


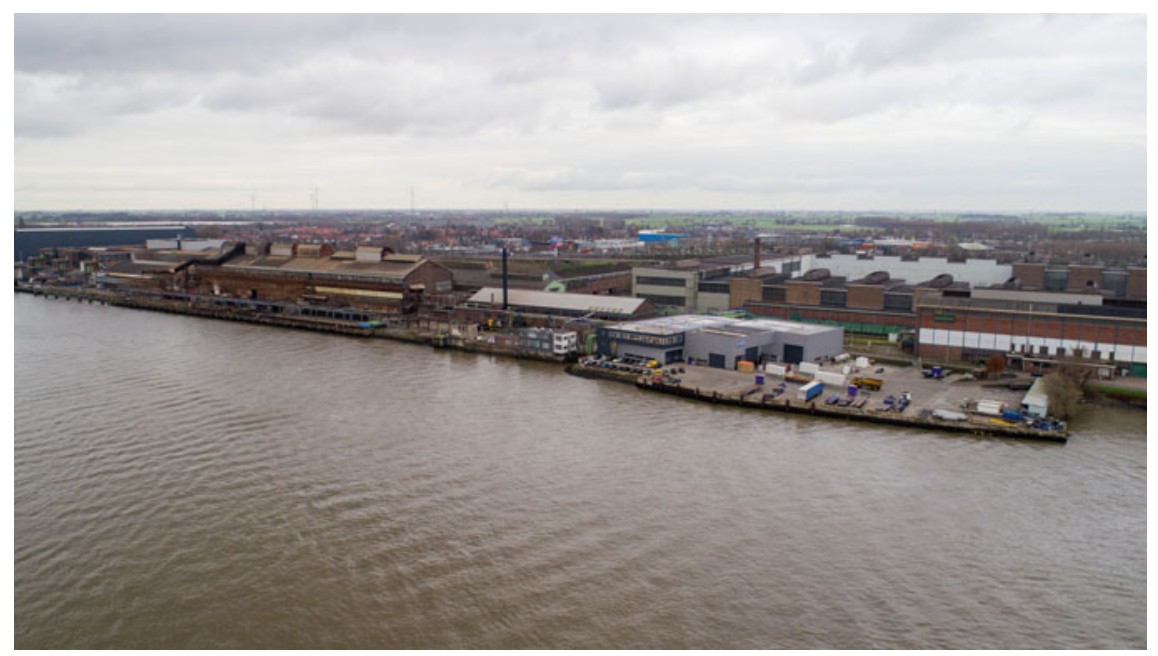

Fig. 4 Aerial view of FNSteel and Nedstaal. Land is owned by Ruigenhil Vastgoed. Photograph Cees van de Wal Fotografie \& Film; released under a Creative Commons AttributionNonCommercial-NoDerivatives 4.0 International License

an icon of the waterfront; the plants themselves were removed by different parties over the course of the year (RHVG 2009).

Not yet removed is the pollution inherited from the integrated steel mill and its steel melting plant; no plan for remediating the site has yet been made. Meanwhile the presidium (the local legislature) has consulted with the other council members of Alblasserdam to prepare for issues that might arise. These consultations were seen as useful after the experience with the spatial redevelopment of the Verolme location in Alblasserdam and similar locations across the Netherlands. The local government wanted to have a clear playing field both economically and socially, and more control in the planning phase free of the market and civil society.

For a redevelopment of this size, the municipality hired ROM-D, whose goal is to strengthen and expand the regional economy, including developing and selling new commercial property, revitalizing existing (outdated) commercial property, developing housing projects, raising the region's profile through promotion, and regional business development. It sees to it that companies will settle at locations right for them and for the region (ROM-D 2010).

The bridge is a symbol of the river and the municipality of Alblasserdam. Recently, the River Art Rotterdam and Drechtsteden Foundation (Stichting River Art Rotterdam \& Drechtsteden) asked artist John Körmeling to develop an attraction on the bridge, and he created Motel Kinderdijk, an actual hotel with rooms overlooking river Noord (Fig. 5 ). This project also has the support of the Economic Development Board of Drechtsteden. On May 8, 2017, the foundation formally handed the proposal for the hotel to the mayors of Alblasserdam, Hendrik-Ido-Ambacht, and Papendrecht. 


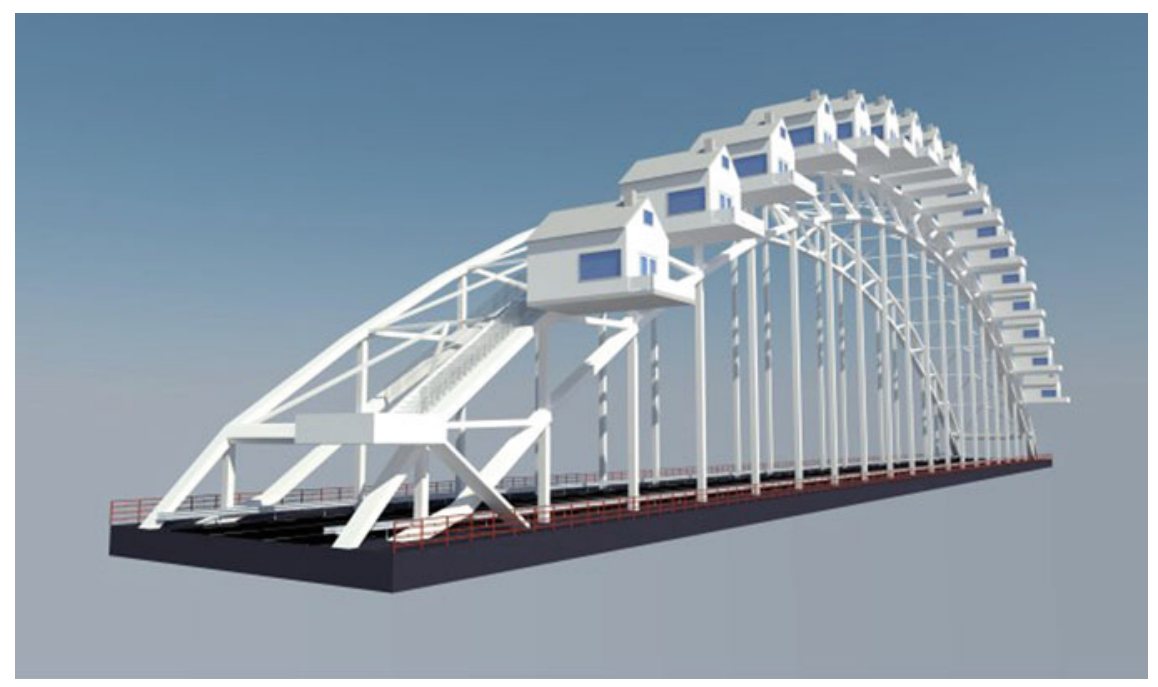

Fig. 5 Maquette of bridge art over the Noord: Motel Kinderdijk. Photograph Gemeente Alblasserdam. Source Het Kontakt 2017; released under a Creative Commons Attribution-NonCommercialNoDerivatives 4.0 International License

To proceed, the foundation will also need approval from Rijkswaterstaat, part of the Ministery of Infrastructure and Environment.

The shipyard once owned by van de Giessen de Noord is now owned by oceAnco. From the river, one sees a modern shipyard with a new dry dock, $156 \mathrm{~m}$ long by $52 \mathrm{~m}$ wide. Much of the old shipyard is gone, including the tall cranes that once distinguished the town's skyline. Only the marine hall remains; here, where workers once constructed polyester minesweepers and minehunters, a new company builds polyester yachts. The Heritage Commission of the municipality of Alblasserdam and the local Historic Society of West-Alblasserdam first objected to demolishing the two remaining tower cranes, but on March 13, 2009, withdrew the objection due to the high cost of keeping them (Homoet 2017, Municipality Alblasserdam 2009). Other huge shipbuilding cranes disappeared from the region when shipyards modernized, closed, or merged with other shipbuilding companies.

The history of this part of the riverfront is told not in structures but in pictures, posters, and other artworks. Working for the Green Heart Foundation (Stichting Groene Hart), two Dutch artists, Marry Teeuwen de Jong and Roel Teeuwen, have designed a new way to maintain the tower cranes as work of art (Teeuwen 2016) a project called Haven Zuid to be located next to oceAnco (Municipality Alblasserdam 2007) (Figs. 6a, b).

The recent financial crisis delayed the project, and it waits for a project developer. Recently, the community of Alblasserdam has selected a work of art by artist Rosalinde van Ingen-Schenau to symbolize the region and serve as a meeting point for tourists (Municipality Alblasserdam 2017). Financed by the municipality and also 
(a)

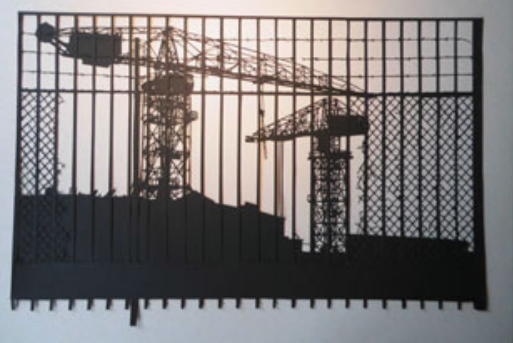

(b)

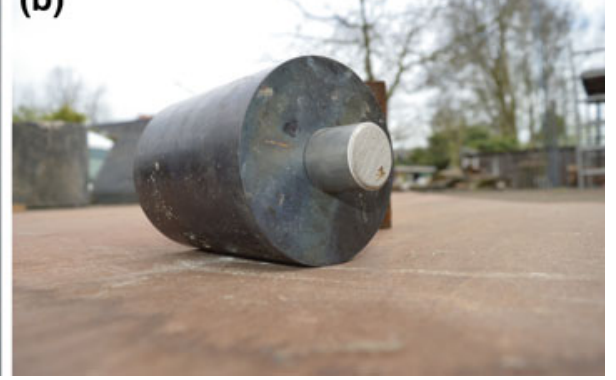

Fig. 6 a (Marry Teeuwen) — view through the fence, $\mathbf{b}$ (Roel Teeuwen) — counterweight of a crane; released under a Creative Commons Attribution-NonCommercial-NoDerivatives 4.0 International License
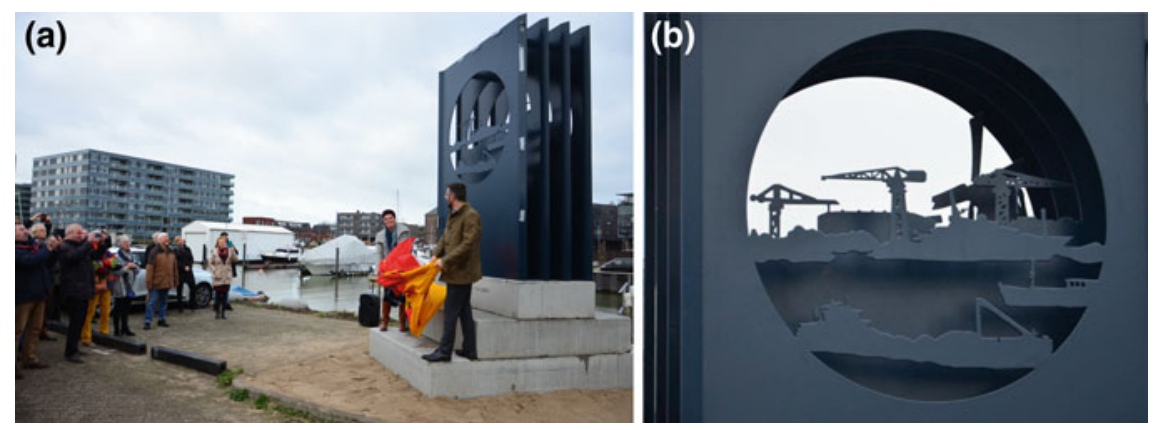

Fig. 7 a and b Anamorphosis with aldermen Arjan Kraijo and Dorien Zandvliet Photograph Gemeente Alblasserdam; released under a Creative Commons Attribution-NonCommercialNoDerivatives 4.0 International License

the province of Zuid-Holland, Anamorphosis was placed in the harbor area at the end of 2017. These works of art are a sort of cultural heritage (Fig. 7).

Similarly, the Oude Werf shipyard is only remembered in pictures and books, and on the Internet (Homoet 2018a). The redevelopment of the site started in March 1952 with filling up the mill pond and dismantling the saw mill (Molen Database 2018). The yard had been owned by Verolme (Verolmetrust 1960) and was sold to van de Giessen de Noord in 1977; in 2000, the yard was acquired by Alblasserdam and a project developer. The area has been redeveloped for houses and apartments overlooking the river. From the river, the visitor can see not only the housing but the jetty for the waterbus that connects Rotterdam and Dordrecht. Near the waterbus stop are other artworks (Municipality Alblasserdam 2014), as part of the town's art route that showcase the identity and the diversity of this port city (Alblasserdam Kunstroute).

In March 2006, the Alblasserwaard city council told the city board to rewrite a plan to develop the Mercon Kloos location (Fig. 8) (ChristenUnie Alblasserdam 2006). But the highest judicial institution in the Netherlands, the Raad van State, decided on 


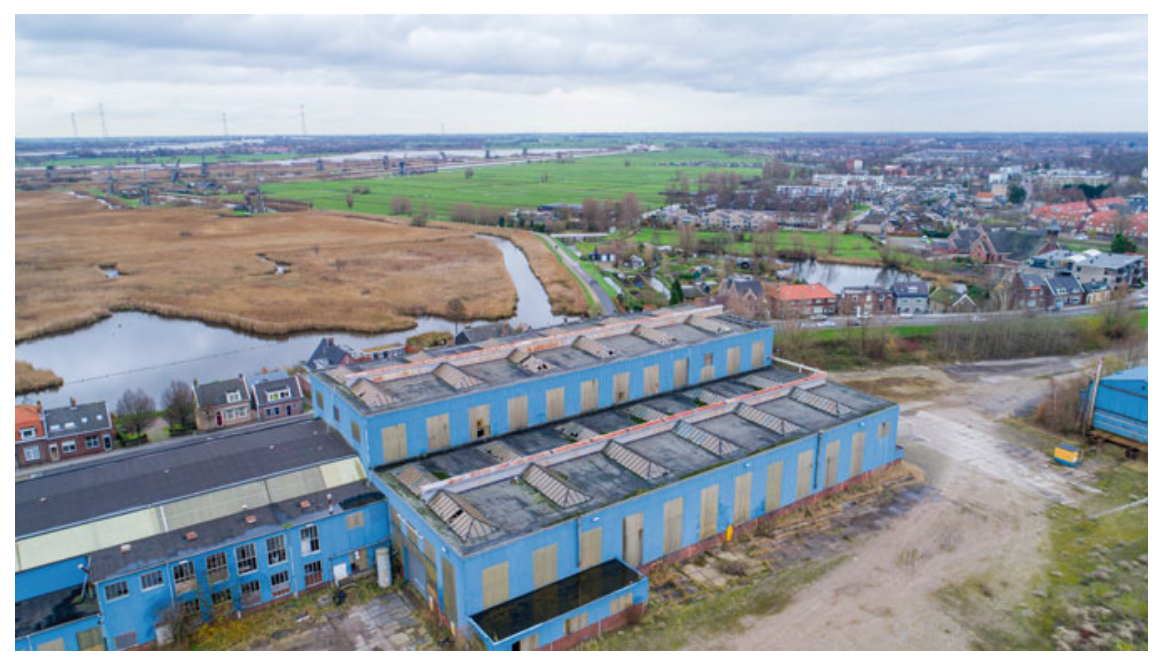

Fig. 8 Mercon Kloos location from the air. Photograph Cees van de Wal Fotografie \& Film (Van der Zouw 2015); released under a Creative Commons Attribution-NonCommercial-NoDerivatives 4.0 International License

Wednesday, November 29, 2010 that the original project of the construction of 300 houses could not proceed. One issue was that the municipality of Alblasserdam had not taken into account the heavy traffic on the Kinderdijk route when planning the new houses, which would bring the number of traffic movements above the maximum threshold. The municipality proposed alternative routes, but the judges decided that better proposals were required. The project was further delayed by the financial crisis. Recently, Mercon Kloos has entered a new phase with the land purchase by project developer Whoonapart (Poldervaart 2017a, b). First meetings with the press and stakeholders have taken place, and early plans now take into account the village landscape, cultural heritage, and heavy traffic. Clearly, the planners have learned from earlier efforts.

Some of the challenging questions and issues remain. What can be kept from the existing iconic buildings depends on the current state of the buildings, especially their steel frames, which have not been maintained. This project is still in development.

Whoonapart and KuiperCompagnons are keen to involve all stakeholders, and have organized several public meetings to this end. The stakeholders have a range of requirements and demands:

Rijkswaterstaat requires a distance of $25 \mathrm{~m}$ between the riverside and housing, mainly for safety, as the Noord is one of the busiest rivers in the Netherlands.

The Waterboard Rivierenland requires that the built-up area be a certain height, because the existing embankment is too low. The Waterboard has decided to reinforce the river side of the embankment because it cannot be made higher due to existing housing. 
The Cultural Heritage Agency of the Netherlands (Rijksdienst voor Cultureel Erfgoed) and Foundation World Heritage Kinderdijk (Stichting Werelderfgoed Kinderdijk) have requirements about the skyline of any new buildings visible from the Kinderdijk mill complex. The current inhabitants along the embankment would like to keep their view to the river. Finally, potential tenants for the hotel, the restaurant, and the museum are making bids based on their business models. Whoonapart is including all of these stakeholder demands in their request for a permit for the development of the Mercon Kloos location. The effort spend in the preliminary phase should shorten the next part of the process of obtaining the required permits from the authorities at local, regional, and national levels.

These five examples show the various ways in which the Dutch preserve cultural heritage for our present and our future. Contemporary art is put in place for improving liveability of the riverfronts and for remembering the past. More attention is paid to the historical tangible and intangible values of buildings, landscapes, and views of sites to be redeveloped.

\section{Networks and Processes}

Today, riverfronts are celebrated by the state, citizens, civil society, and the market as desirable spaces for sustainability and liveability of neighborhoods, villages, towns, and cities. This celebration generates self-organized initiatives by citizens and civil society within the scope of redevelopment plans of the riverfront landscape. So, as is shown with the riverfront and the forelands of the Noord, more and more actors are getting involved in the spatial development of waterfronts.

Once a center of industrial activity, the Alblasserwaard river area is now a mix of industrial activity, housing, and leisure, with heritage values as a continuous thread through all actions. All actors operate in networks bringing together social, human, and information capital to achieve their different objectives; they pursue processes that link them with each other, whether in agreement or in ongoing discussions. In line with recent concerns about citizens' involvement in the Netherlands (Van Dam et al. 2014), this section highlights three citizen initiatives restoring and managing cultural heritage in the Alblasserwaard and the river Noord.

First, the Water Triangle is one of seven defined heritage lines in the province of Zuid-Holland (Province Zuid-Holland 2015a, b). A heritage line is a geographic line connecting various points on the map to create a coherent whole in harmony with a common historical narrative. These points could also frame a linear feature, but they need a common story. The aim of naming objects as a heritage line is to make the cultural landscape more visible. Other lines include the fortifications marking the Roman frontier, the former transport routes along the many canals, and former defense structures in water. The Water Triangle heritage line connects the iconic towns Biesbosch, Dordrecht, and Kinderdijk and the area in the triangle they form. Much has been invested in the Unesco Mill Network Elshout/Kinderdijk, a group of windmills in an exceptional human-made landscape that illustrates the centuries-long 


\section{Ambitiekaart}

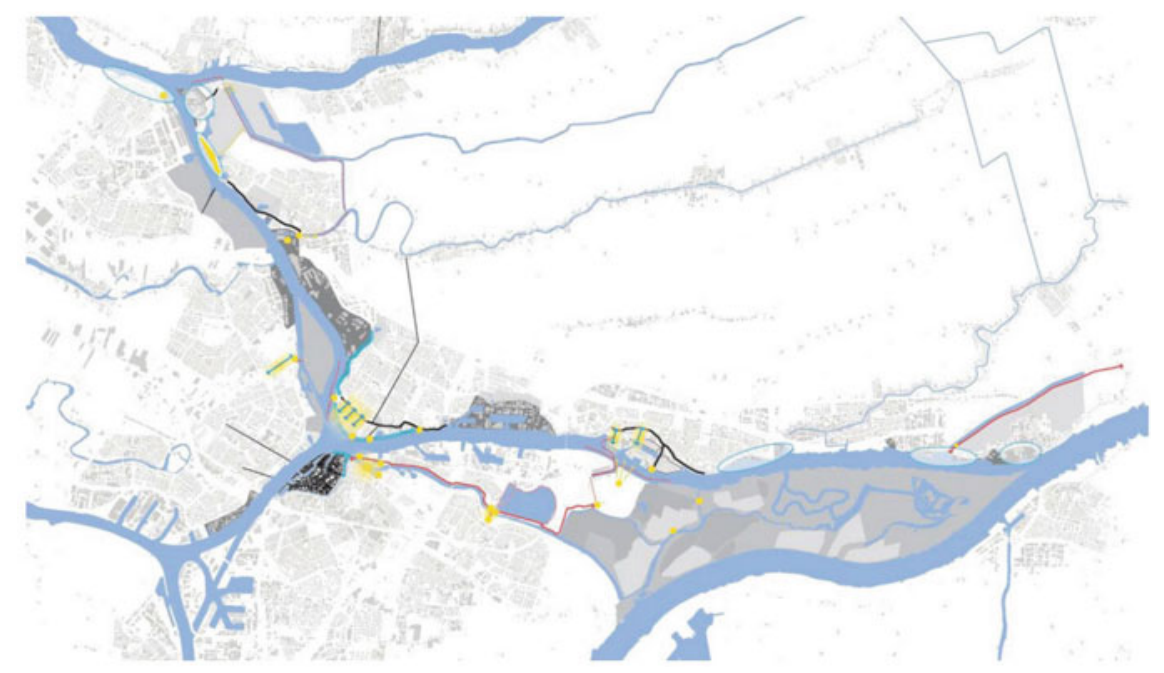

Fig. 9 Ambition map of heritage line water triangle (Waterdriehoek) Province South Holland; released under a Creative Commons Attribution-NonCommercial-NoDerivatives 4.0 International License

battle of the Dutch people to drain parts of their territory and protect them against further inundation. Now a tourist attraction, all the major elements of the complex system have survived (Unesco 1997).

The question of which items to include in a heritage line is one of provincial policy making, part of which is supposed to emerge from bottom-up pressure. Stakeholders who want to discuss heritage and might propose activities to preserve or create heritage meet three to four times a year in heritage committees and they advise the province which projects to subsidize. Typically, September meetings are reserved for judging project proposals from members of the Water Triangle heritage line (Fig. 9).

A second citizen initiative is the RiverArt project, which uses art to connect river towns. It aims to realize 25 art projects in 2025. It was started by the Economic Development Board and is also a project of Dordrecht (which is also part of the Water Triangle heritage line) and Rotterdam. It is an integrated area development project to reinforce riverfront quality with attention to heritage and public space. The first art project is the Floating Forest in the Rijnhaven of Rotterdam (in Dutch dobberend bos), a collection of twenty trees floating water on recycled sea buoys in the Rijnhaven, a downtown harbor basin. The installation is a green spot in the port, calling attention to art, innovation, and sustainability (Port of Rotterdam 2016).

The third citizen initiative is a vantage point on the Groote Zaag in Krimpenerwaard: the fourteen meter high Beaver bridge, designed by Ruud Reutelingsperger of the artists' collective Observatorium. The bridge, a structure of steel tubes, is 
inspired by Beaver castle. From it, you have a panoramic view over The Saw (De Zaag), Rotterdam, the port, and the river (Zuid-Hollands Landschap 2018).

\section{Conclusion}

This chapter is a first step in discussing the neglected and undervalued culture heritage of riverfronts in the Alblasserwaard and what people are doing to develop and preserve them. A next step, which could help a deeper analysis of the case study of the Alblasserwaard and its many stakeholders, would relate to the process of valuing this heritage to ideas of negotiation; the IAD model by Ostrom (2005), the CLEAR model by Lowndes (Lowndes et al. 2006), the process of bonding and bridging by Putnam (2001) and of linking by Szreter (Szreter and Woolcock 2004), and the civic voluntarism model of Verba (Verba et al.1995). Possible linkages can be established between these different ways of working. The IAD model from Ostrom could define boundaries of the "action arena" with actors and situations, whereas the CLEAR model could define required and preferred capacities of participants. Putman and Szreter allow us to define the processes that take place with networks and between networks. Bonding takes place between like-minded actors, bridging notlike-minded actors with equal power positions, and linking not-like-minded actors in unequal power positions.

The conceptual model (Fig. 10) shows that the local government has rules to obey and depends on the social, physical, and economic conditions of its locality. The spatial bonding process takes place between directly involved actors.

As discussed, much has been already invested in works of art along the river banks to make the river areas and the region more visible and attractive to investors and tourists. Former construction plants are turned into housing areas, including the jetty for the waterbus and options for hotels, a restaurant, and a museum of local water management. The new owner Whoonapart says that he looks for best practices on the Internet to deal with his property and seeks to listen to all stakeholders.

This chapter considered two shipyards, one steel mill, one construction plant, and a traffic bridge in a municipality on the river bank of the river Noord: witnesses of the past, the present, and the future of water and heritage in the region. In the past, the economic value of the property was the main factor valued by owners and municipalities. Citizens and civil society had a vote and maybe a voice, but economic value (within the applicable laws and rules) settled most decisions. Now, the game is different. With the changing economic value of the area, and also changing values concerning the area's history and future, and with the public having a stronger voice, citizens' initiatives, and involvement are more important to the process of valuing and transforming property and land along the river. This new complexity is highly valued by municipal authorities, but also brings along a need for more scientific research on transforming forelands from industrial landscapes in ways that preserve that same industry and related identity within a diversity of voices on water and heritage. 


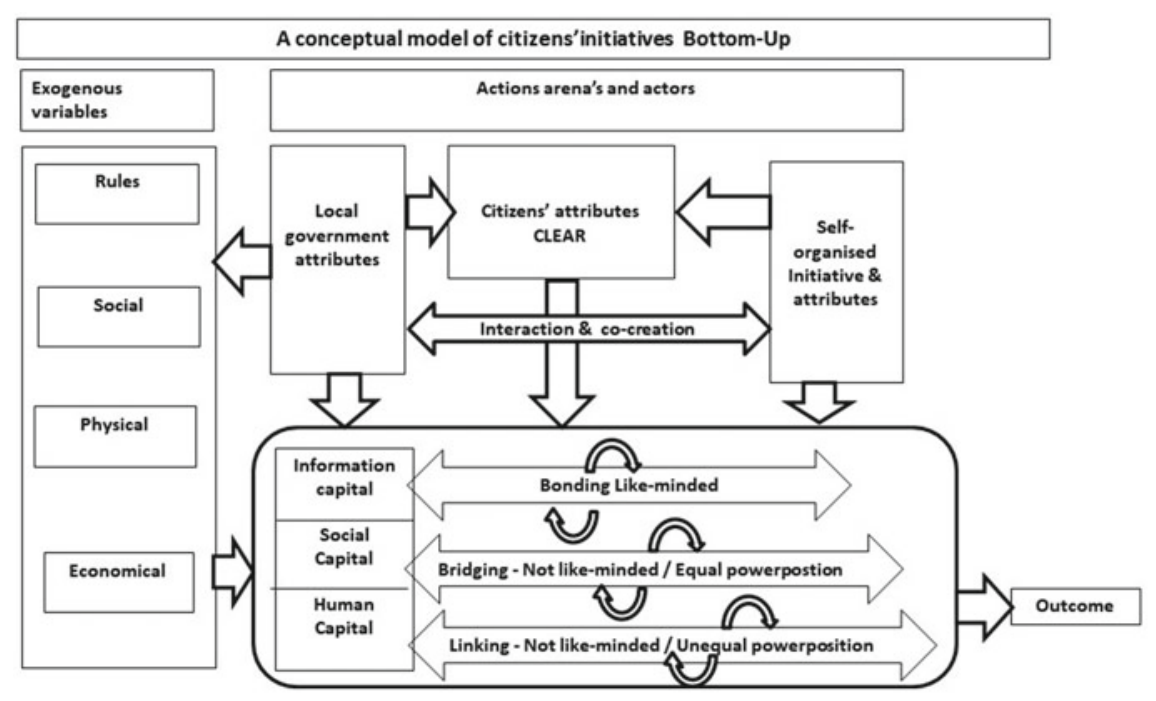

Spatial bonding process

Fig. 10 Conceptual model of citizens'initiatives (bottom-up); released under a creative commons attribution-Non Commercial-No Derivatives 4.0 International License

\section{References}

Alblasserdam.net (2018) Retrieved 1 January 2018, from https://www.alblasserdam.net/column/ 2015-08-25/cornelis-verolme-blijft-voor-eeuwig-aan-alblasserdam-verbonden-.html

Autosnelwegen (2018) Openingsdata nieuwe autosnelwegen. Retrieved 29 June 2018, from https:// www.autosnelwegen.nl/index.php/geschiedenis/5-1940-1945-tweede-wereldoorlog

BBN adviseurs (2009, March 30) Herontwikkeling Scheepswerf Verolme Alblasserdam. Retrieved 29 June 2018, from http://www.bbn.nl/gebiedsontwikkeling/projecten/507/herontwikkelingscheepswerf-verolme-alblasserdam.html

Boersma P (1939) Alblasserdam's heden en verleden, Europese Bibliotheek-Zaltbommel

Bouwcombinatie Alblasserwerf (2004) Alblasserwerf. Retrieved 29 June 2018 http://www.boele. nl/projecten/alblasserwerf-de-hellingen-alblasserdam

ChristenUnie Alblasserdam (2006, November 3). Mercon Kloos. Retrieved 25 Sept 2017, from https://alblasserdam.christenunie.nl/k/news/view/136109/543294/tegenstem-begrotingchristenunie.html

De Reus, M.J.C. (1998) Alblasserdam 1299-1999. Gemeente Alblasserdam, ISBN: 90-76540-13-6

De Wit S (2009) Dutch Lowlands morphogenesis of a cultural landscape. Uitgeverij SUN and author, Amsterdam

Deal Drecht Cities (2018, Februari 22). Alblasserdam. Retrieved 29 June 2018, from https://www. dealdrechtcities.nl/drecht-cities/alblasserdam/

Estevens A (2005) Waterfronts rehabilitation. Retrieved 4 Oct 2017, from http://www.isocarp.net/ Data/case_studies/636.pdf

HafenCity Hamburg (2000) Architecture. Retrieved 4 Oct 2017, from https://www.hamburg.com/ sights/architecture/hafencity-hamburg/

HafenCity Hamburg (2017) Masterplan. Retrieved 4 Oct 2017, from https://www.hafencity.com/ en/glossary/glossary-i-m.html\#masterplan

Harms H (2007) Changes on the waterfront - transforming harbor areas comparison and evaluation of waterfront developments in two contexts. In: San Francisco Bay Area and Hamburg, Germany 
Preliminary Presentation at Shrinking Cities Conference, University of California, Berkeley Feb 2007, p 14

Harms H (2008) Changes on the waterfront-transforming Harbor Areas: comparison and evaluation of waterfront developments in two contexts: San Francisco Bay Area and Hamburg, Germany, IURD Working Paper Series, Institute of Urban and Regional Development, pp 37-48, UC Berkeley

Het Kontakt (2017) Retrieved 20 October 2017, from https://www.hetkontakt.nl/regio/ alblasserwaard/algemeen/119603/motel-kinderdijk-kunstidee-voor-brug-over-de-noord

Homoet C (2018a) Oude Werf. Retrieved 29 June 2018, from http://www.scheepsbouwalblasserdam.nl/oude-werf.html\#

Homoet C (2017) Torenkraan. Retrieved 20 Oct 2017, from http://www.scheepsbouw-alblasserdam. nl/torenkraan-23-April-2009.html

Homoet C (2018b) Werf de Noord. Retrieved June 29, 2018, from http://www.scheepsbouwalblasserdam.nl/torenkraan-23-april-2009.html

HVE Architecten (2001) Verolme terrein Alblasserdam. Retrieved 1 Jan 2018, from http://hvearchitecten.nl/projecten/verolme-terrein-alblasserdam/

Louwe Kooijmans LP (1974) The rhine/meuse delta: Four studies on its prehistoric occupation and holocene geology, Leiden, Analecta Praehistorica Leidensia 7

Lowndes V, Pratchett L, Stoker G (2006) Local political participation: the impact of rules in use. Public Adm 84(3):539-556

Molen Database (2018) Molen Ons Genoegen. Retrieved 1 Jan 2018, from http://www. molendatabase. $\mathrm{org} / \mathrm{molendb}$.php?step $=$ details\&nummer $=866$

Municipality Alblasserdam (2009, March 13), Torenkraan. Retrieved 28 June 2018 from https:// www.alblasserdam.nl/albdam/up1/ZetddqbIwC_Behoud_torenkranen_helaas_te_duur.pdf.

Retrieved June 28, 2018

Municipality Alblasserdam (2012) Alblasserwerf. Retrieved 29 June 2018, from https://www. alblasserdam.n1/werk-in-uitvoering/bouwprojecten/alblasserwerf

Municipality Alblasserdam (2007, March 24) Haven Zuid. Retrieved 4 Sept 2017, from https:// www.alblasserdam.nl/albdam/up1/ZydikabIqC_120.pdf

Municipality Alblasserdam (2014) Kunstroute. Retrieved 24 Sept 2017, from https://www. alblasserdam.nl/albdam/up1/ZuidaqoJC_kunstroute.pdf

Municipality Alblasserdam (2017, May 22) Kunstwerk. Retrieved 24 Sept 2017, from https:// www.alblasserdam.nl/actueel/nieuwsarchief/may-2017/kies-een-kunstwerk-voor-het-nieuwehavengebied

Ostrom E (2005) Understanding institutional diversity. Princeton University Press

Poldervaart J (2017a, September 11) Nieuwe bestemming voor het gebied Mercon-Kloos. Retrieved 20 Oct 2017, from https://www.alblasserdam.net/nieuws/2017-09-11-10003-nieuwebestemming-voor-het-gebied-mercon-kloos.html

Poldervaart J (2017b, September 26) Ontwikkeling Mercon Kloos terrein. Retrieved 22 Oct 2017, from http://www.alblasapart.nl/

Port of Rotterdam (2016, March 17) The port has gained a floating forest. Retrieved 31 Mar 2018, from https://www.portofrotterdam.com/en/news-and-press-releases/the-port-has-gaineda-floating-forest

Province Zuid-Holland (2015a) Erfgoedlijn Waterdriehoek. Retrieved on 25 Sept 2017, from https:// www.zuid-holland.n1/@9212/nieuwe/

Province Zuid-Holland (2015b). Zuid-Holland: slimmer, schoner en sterker. Retrieved 28 June 2018, from https://www.zuid-holland.nl/publish/pages/10694/zuidhollandslimmerschonerensterkerhoofdlijnenakkoord2015-2019.pdf

Putnam RD (2001) Social capital: measurement and consequences. Isuma Can J Policy Res [Internet]. 2:41-51

RHVG (2009) Ontmanteling installaties.Retrieved 28 June 2018, from http://www.rhvg.nl/themasen-projecten/actueel/23-ontmanteling-installaties

ROM-D (2010) Drechtsteden. Retrieved 29 June 2018, from https://www.rom-d.nl/drechtsteden 
Rotterdam District Court (2014, October 20), Netherlands steelmaker Nedstaal files for bankruptcy. Retrieved 29 June 2018, from https://www.metalbulletin.com/Article/3391545/Netherlandssteelmaker-Nedstaal-files-for-bankruptcy.html

Szreter S, Woolcock M (2004) Health by association? Social capital, social theory, and the political economy of public health. Int J Epidemiol 2004(33):650-667

Teeuwen R (2016, Februari 29) Kunstenaars laten mogelijkheden met oude torenkranen zien. Retrieved 29 June 2018, from http://www.alblasserdamsnieuws.nl/wordpress/2016/02/29/ kunstenaars-laten-mogelijkheden-met-oude-torenkranen-zien/

Telegraaf (2014, October 17). Staalproducent Nedstaal failliet. Retrieved 28 June 2018, from https:// www.telegraaf.nl/financieel/894917/staalproducent-nedstaal-failliet

UNESCO (1997). Mill Network at Kinderdijk-Elshout. Retrieved March 13, 2018, from http://whc. unesco.org/en/list/818

Van Dam R, Salverda IE, During R (2014) Strategies of citizens' initiatives in the Netherlands: connecting people and institutions. Crit Policy Stud 8(3):323-339

Van der Zouw H (2015, August 25) Cornelis Verolme blijft voor eeuwig aan Alblasserdam verbonden. Retrieved 29 June 2018, from https://www.alblasserdam.net/column/2015-08-25/cornelisverolme-blijft-voor-eeuwig-aan-alblasserdam-verbonden.html

Van Groningen CL (1992) De Alblasserwaard. Waanders Uitgevers, Zwolle/Rijksdienst voor de Monumentenzorg, Zeist 1992

Verba S, Schlozman KL, Brady HE (1995) Voice and equality: civic voluntarism in American politics. Harvard University Press

Verolmetrust (1960, October 11) Geschiedenis. Retrieved 9 Feb 2018, from http://www. verolmetrust.nl/geschiedenis/

Whyte WH (1975) The social life of small urban spaces. Retrieved 5 Jan 2018, from https://www. pps.org/about

Zuid-Hollands Landschap (2018) De Zaag en Stormpoldervloedbos in de Nieuwe Maas. Retrieved 29 June 2018, from https://www.zuidhollandslandschap.nl/gebieden/de-zaag-enstormpoldervloedbos

Arie den Boer is External Ph.D. candidate at Erasmus University Rotterdam, the Netherlands. His research interests include citizen participation, urban redevelopment in harbor and waterfront areas, and water-bound heritage. His articles include "Obstacles and changes during the decisionmaking process from citizens' initiative to a plan of reconstruction" (RLICC 2018) and "Is reconstruction of a lock worthwhile by enhanced insights?" (RLICC 2015).

Open Access This chapter is licensed under the terms of the Creative Commons AttributionNonCommercial-NoDerivatives 4.0 International License (http://creativecommons.org/licenses/bync-nd/4.0/), which permits any noncommercial use, sharing, distribution and reproduction in any medium or format, as long as you give appropriate credit to the original author(s) and the source, provide a link to the Creative Commons license and indicate if you modified the licensed material. You do not have permission under this license to share adapted material derived from this chapter or parts of it.

The images or other third party material in this chapter are included in the chapter's Creative Commons license, unless indicated otherwise in a credit line to the material. If material is not included in the chapter's Creative Commons license and your intended use is not permitted by statutory regulation or exceeds the permitted use, you will need to obtain permission directly from the copyright holder.

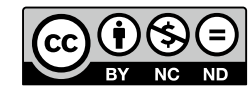

